DOI: $10.17516 / 1997-1389-0291$

УДК 597.553.2:597-14.087:597-16

\title{
Morphological Features and Endoparasite Fauna of Some Whitefishes and Grayling Fishes from the Eastern Part of Lake Sobachye (the Putorana Plateau)
}

Vladimir I. Romanova, Kseniya V. Polyaeva ${ }^{\text {b* }}$ and Yulia S. Nikulina ${ }^{a}$ ${ }^{a}$ National Research Tomsk State University 36 Lenin, Tomsk, 634050, Russia ${ }^{b}$ Krasnoyarsk Branch of the FSBSI "VNIRO" 33 Parizhskoj Kommuny, Krasnoyarsk, 660049, Russia

Received 16.11.2016, received in revised form 30.11.2016, accepted 25.03.2019, published online 08.04.2019

The present study addresses the morphological features of cisco, round whitefish and grayling. These fish species are the most abundant representatives of Coregonidae and Thymallidae in the eastern part of Lake Sobachye. The local cisco (Coregonus sp.) is closer to vendace (Coregonus albula) than to least cisco (Coregonus sardinella) in its diagnostic features. Ciscoes with a low number of vertebrae (the average number significantly below 60) were previously found in the Khantayka River and Khatanga River basins. C. sardinella is a cisco with a high number of vertebrae (more than 60 on average), which inhabits all basins, along with cisco populations that have a low number of vertebrae. Analysis of mitochondrial DNA polymorphism (mtDNA) of the cisco (Coregonus sp.) from Lake Sobachye showed a significant similarity between this population and the cisco from European water bodies (C. albula). The basic meristic traits of the round whitefish (Prosopium cylindraceum) from Lake Sobachye and other lakes of the Putorana Plateau are considered in the present study. The round whitefish in the water bodies of the Norilo-Pyasinskaya system is represented by a single population. All known groups of the Taymyr round whitefish are rightfully considered as typical representatives of the "Arctic" group. Thus, there is no reason to distinguish between the "Arctic" and "Boreal" groups. The round whitefish in the water bodies of the Norilo-Pyasinskaya system is represented by river and lake-river forms. For the first time, complete morphological characterization of the Siberian grayling (Thymallus arcticus) has been given for this region. Research of parasite fauna of cisco, round whitefish, Siberian grayling and whitefish (Coregonus lavaretus) showed that Lake Sobachye is a site of diphyllobothriasis. The cestode Diphyllobothrium dendriticum carriers are whitefish (C. lavaretus) and cisco (Coregonus sp.).

(C) Siberian Federal University. All rights reserved

This work is licensed under a Creative Commons Attribution-NonCommercial 4.0 International License (CC BY-NC 4.0).

* Corresponding author E-mail address: glechoma21@gmail.com 
Compared with the results of previous studies, the rate of fish infestation with parasites associated with the zooplanktonic organisms has increased: the prevalence of cisco by D. dendriticum has increased from 73\% (2002-2004) to 96\%, and the average intensity of parasitic infestation has increased from 4 to 8 individuals.

Keywords: morphology, parasite fauna, cisco fishes, grayling fishes, Lake Sobachye.

Citation: Romanov V.I., Polyaeva K.V., Nikulina Yu.S. Morphological features and endoparasite fauna of some whitefishes and grayling fishes from the eastern part of Lake Sobachye (the Putorana Plateau). J. Sib. Fed. Univ. Biol., 2019, 12(4), 410-429. DOI: $10.17516 / 1997-1389-0291$

\title{
Морфологические особенности
}

\section{и эндопаразитофауна некоторых сиговых \\ и хариусовых рыб в восточной части озера Собачье (плато Путорана)}

\author{
В.И. Романов ${ }^{\text {, }}$ К.В. Поляева ${ }^{6}$, Ю.С. Никулина ${ }^{\mathrm{a}}$ \\ ${ }^{a}$ Национальный исследовательский \\ Томский государственный университет \\ Россия, 634050, Томск, пр. Ленина, 36 \\ ${ }^{6}$ Красноярский филиал ФГБНУ «ВНИРО» \\ Россия, 660049, Красноярск, ул. Парижской коммуны, 33
}

В статье представлены материаль исследования морфологических признаков ряпушки, сига-валька и сибирского хариуса - наиболее массовых представителей семейств сиговых и хариусовых рыб из восточной части оз. Собачье. Показано, что местная ряпушка по своим диагностическим признакам ближе к европейской - Coregonus albula, нежели к сибирской C. sardinella. Ранее малопозвонковые ряпушки со средними значениями числа позвонков существенно менее 60 были обнаружены в бассейнах рек Хантайки и Хатанги. Во всех бассейнах присутствуют как малопозвонковые популяции, так и многопозвонковые (в среднем более 60), к которым относится C. sardinella. Анализ полиморфизма митохондриальной ДНК (мтдНК) ряпушки (Coregonиs sp.) оз. Собачье показал значительную близость этой популяции и ряпушек из европейских водоемов - C. albula. Рассматриваются основные меристические признаки обыкновенного валька (Prosopium cylindraceum) оз. Собачье и других озер плато Путорана. Показано, что валек в водоемах Норило-Пясинской системы представлен единой популяичией. Все известные группировки валька Таймыра правомочно считать типичными представителями «арктической» группы, оснований для выделения «арктической» и «бореальной» группировок нет. Сиг-валек в водоемах Норило-Пясинской системы представлен речной и озерно-речной формами. Впервые приведено полное морфологическое описание сибирского хариуса (Thymallus arcticus) для этого региона. Исследования паразитофауньл 
перечисленных видов и сига-пыжьяна показали, что оз. Собачье - очаг распространения дифиллоботриоза. Носителями цестоды Diphyllobothrium dendriticuт являются сиговые рыбыряпушка и сиг. По сравнению с результатами предыдущих исследований возросли показатели зараженности рыб паразитами, связанными жизненным ициклом с зоопланктонными организмами: экстенсивность инвазии ряпушки D. dendriticum возросла с 73 (2002-2004 гг.) до $96 \%$, интенсивность инвазии - с 4 до 8 экз.

Ключевые слова: морфология, паразитофауна, сиговые и хариусовые рыбы, оз. Собачье.

Цитирование: Романов, В.И. Морфологические особенности и эндопаразитофауна некоторых сиговых и хариусовых рыб в восточной части озера Собачье (плато Путорана) / В.И. Романов, К.В. Поляева, Ю.С. Никулина // Журн. Сиб. федер. ун-т. Биология, 2019. 12(4). С. 410-429. DOI: 10.17516/1997-1389-0291

\section{Введение}

В горах (плато) Путорана сосредоточено большое количество озер - самых крупных в Сибири после оз. Байкал. Особенно в этом отношении интересен западный сектор плато. Озера, находящиеся здесь, относятся к бассейну р. Хантайки, правого притока Енисея, и бассейну р. Пясины. По площади крупнейшие из них (Хантайское, Лама, Кета, Глубокое, Собачье) если и уступают таким озерам, как Таймыр и Пясино, то характеризуются значительно большими глубинами, а следовательно, и большими объемами водной массы. Для многих из них либо отсутствуют, либо имеются лишь приблизительные данные по глубинам, которые часто нуждаются в уточнении.

Среди крупных озер бассейна Пясины, входящих в состав водоемов плато Путорана, Собачье (Ыт-Кюэль) занимает пятое место по площади (99,0 км²). Протяженность озера 46 км, ширина - до 3,7 км, максимальная глубина - 162 м (Пармузин, 1981). Из озера вытекает р. Муксун (длина 20 км), соединяющая Собачье с оз. Глубокое. Уже с начала рыбного промысла в этом регионе оз. Собачье вошло в состав важных рыбохозяйственных объектов Норильских озер и до организации Путоранского государственного природно- го заповедника (создан в 1988 г.) основным объектом рыбодобычи являлась местная крупная форма ряпушки (Ледяев, Романов, 1991). Она же стала и объектом первых ихтиологических исследований, проведенных на этом водоеме сотрудницей Красноярского отделения СибНИИРХ О.Л. Ольшанской (Ольшанская, 1964, 1967). В последующем некоторая информация по рыбам оз. Собачье была опубликована сотрудниками кафедры ихтиологии Московского госуниверситета (Павлов и др., 1994; Максимов и др., 1995; Савваитова и др., 1996; Павлов и др., 1999). Кроме ряпушки, исследовалась структура гольцовой фауны (род Salvelinus) и некоторые другие виды лососеобразных рыб. Эти исследования обычно были представлены небольшими по объему материалами, хотя охватывали кроме оз. Собачье и другие водоемы бассейна р. Пясины.

Образование в 2013 г. объединенной дирекции ФГБУ «Заповедники Таймыра» стимулировало организацию исследований видового состава и особенностей биологии рыб на подконтрольных участках заповедных и буферных зон. При этом ихтиофауна оз. Собачье стала одним из основных объектов этих исследований (Заделенов и др., 2014; Заделенов и др., 2015; Романов и др., 2016). 
Хотя ихтиофауна оз. Собачье уже имеет свою историю исследования, данных по биологии рыб, за исключением ряпушки, всетаки крайне мало. Состав ихтиофауны этого водоема оценивается не менее чем в 30 видов и подвидов рыб. Очень разнообразна фауна гольцов (род Salvelinus) этого озера. На наш взгляд, она может оказаться сложнее таковой из озер Лама, Кета и Глубокое. Слабо изучены сиговые и хариусовые рыбы оз. Собачье. Не проводилось изучение пространственного распределения и видового состава рыб по акватории этого водоема. Состав рыб и их доминирующие представители отличаются в восточной и западной частях озера. Недостаточно исследований паразитофауны гидробионтов, а в уже имеющихся публикациях большее внимание пока уделялось изучению состава паразитов у некоторых массовых представителей сиговых рыб (Романов и др., 2016; Рудковский, Бочарова, 2007).

Цель настоящей публикации - дополнить материалы ранее опубликованных работ и привести новые данные по морфологии и паразитологии для некоторых массовых представителей сиговых и хариусовых рыб, встречающихся в восточной части оз. Собачье.

\section{Материалы и методы}

Исследования рыб на оз. Собачье проходили в районе кордона заповедника «Путоранский», в районе устья р. Хоронен. В качестве сравнительного материала были использованы дополнительные данные по ряпушке, сигу-вальку и сибирскому хариусу из озер Кета и Лама (рис. 1). К числу наиболее массовых видов рыб здесь, по нашим наблюдениям, относятся местная малопозвонковая ряпушка (Coregonus sp.), сиг-валек (Prosopium cylindraceum (Pennant, 1784)), сибирский хариус (Thymallus arcticus
(Pallas, 1776)), несколько форм гольцов (род Salvelinus) и налим (Lota lota (Linnaeus, 1758)). Остальные представители (сиг-пыжьян (C. pidschian (Gmelin, 1789)), чир (C. nasus (Pallas, 1776)) и др.) встречаются здесь очень редко, и достаточно полноценного материала по ним собрать не удалось, хотя, по сообщению работников заповедника, в западной части озера, в районе истока р. Муксун, эти рыбы наблюдаются гораздо чаще.

Изучению морфологических признаков уделялось основное внимание, поскольку у рыб (кроме ряпушки) оз. Собачье ранее они исследовались явно недостаточно и часто публикации базировались на нерепрезентативных материалах. В некоторых случаях авторы даже не указывали объем исследованного материала. Нами анализировались меристические и пластические признаки рыб. Объем исследованного материала по морфологии рыб представлен в тексте и таблицах. Кроме того, для сравнения были использованы собственные сборы по ряпушке и сигу-вальку, проведенные нами ранее (1983 г.) на оз. Лама. Исследование морфологических признаков рыб проводилось согласно общепринятым методикам (Правдин, 1966; Романов и др., 2012). Подсчет позвонков у ряпушек шел в полевых условиях с учетом рекомендаций Ю.С. Решетникова (1980). Рудиментарный позвонок не учитывался.

Методом специального паразитологического вскрытия было обработано 70 экз. рыб: 22 экз. ряпушки; 15 экз. сига-пыжьяна (сиг); 18 экз. сига-валька и 15 экз. сибирского хариуса. Сбор, фиксацию и камеральную обработку паразитологических проб проводили по общепринятым методикам (Быховская-Павловская, 1985). Для видовой идентификации паразитов использовали определители (Определитель..., 1984, 1985, 1987). При видовой идентификации скребней 


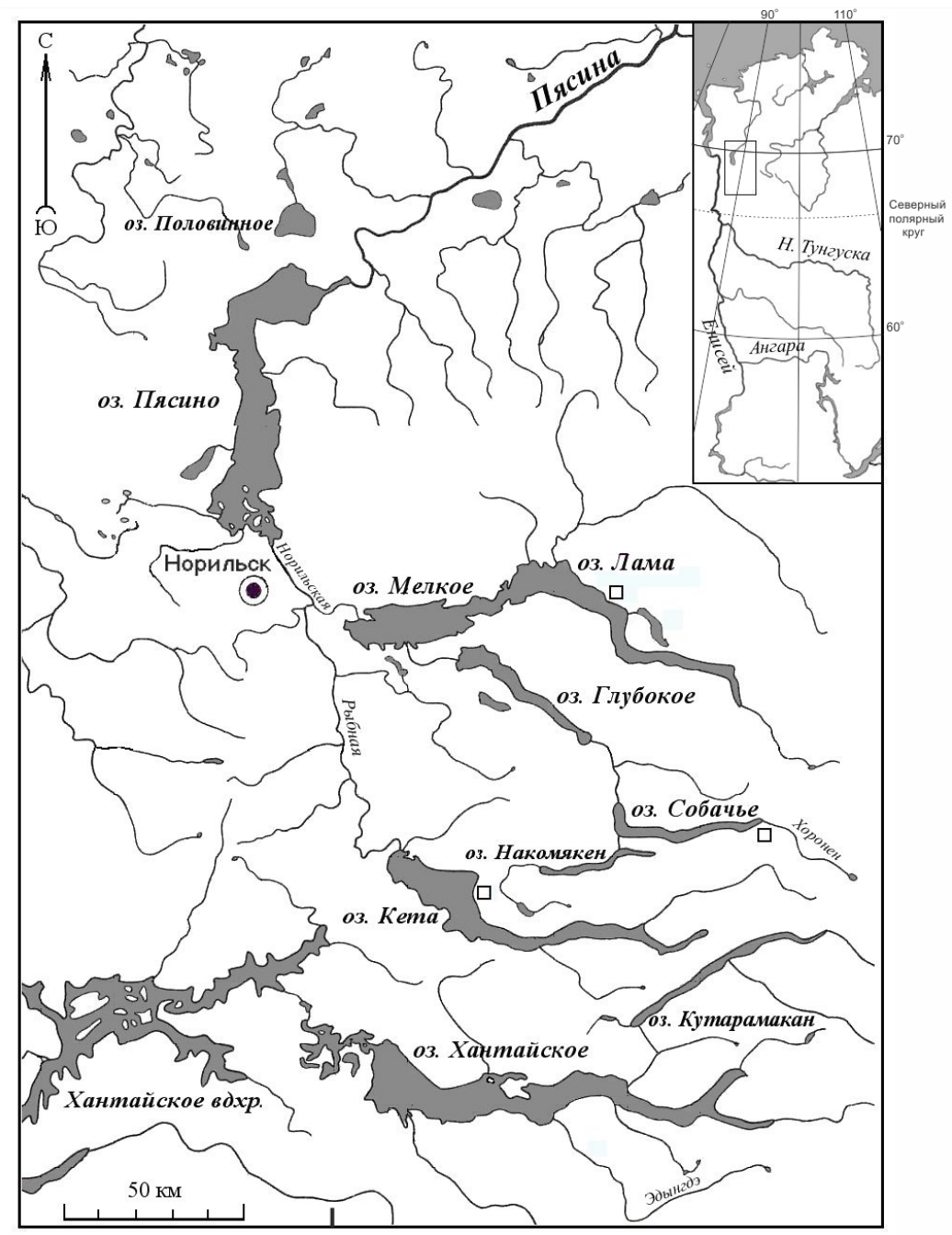

Рис. 1. Карта-схема северо-западного сектора плато Путорана: места сбора материала обозначены $\square$

Fig. 1. A diagrammatic map of the northwestern sector of the Putorana Plateau: sampling positions are marked $\square$

рода Neoechinorhynchus применяли статьюопределитель О.М. Амина с учетом поправок, предложенных Е.И. Михайловой (Amin, 2002; Михайлова, 2010). Классификация скребней дается на основе классификации О.М. Амина (Amin, 2013).

Статистическая обработка материала осуществлялась общепринятыми методами (Лакин, 1980). Статистический анализ зараженности проводился с помощью программы Quantitative Parasitology 3.0 (Rozsa et al., 2000).

\section{Результаты и обсуждение}

К числу наиболее массовых рыб в восточной части оз. Собачье можно отнести ряпушку, сига-валька, сибирского хариуса и гольцов (род Salvelinus), которые здесь представлены рядом форм (Павлов и др., 1994; Заделенов и др., 2014, 2015). По трем видам отражены данные по морфологии и паразитологии.

\section{Ряпушка-Coregonus sp.}

К ряпушкам Евразии относят два вида европейская (C. albula (L.)) и сибирская 
(C. sardinella Val.). Ареал европейской ряпушки - это бассейны Северного, Балтийского, Баренцова и Белого морей (Атлас..., 2002). Считается, что в районе р. Печоры происходит перекрывание ее ареала с ареалом сибирской ряпушки (Атлас..., 2002; Решетников, 1980; Соловкина, 1974). Важные замечания по диагностике, анализу ценности некоторых меристических признаков и статусу печорских ряпушек имеются у Г.П. Сидорова и Ю.С. Решетникова (2014). Бассейны р. Кары и сибирских рек населяет уже сибирская ряпушка, ареал которой продолжается далее на восток, захватывая и Североамериканский континент. Был период, когда их рассматривали не выше ранга подвида. Определенные проблемы с точной диагностикой этих видов вызвали в свое время активную дискуссию по этому поводу (Дрягин и др., 1969; Пирожников и др., 1975). Речь шла об основных диагностирующих критериях, предложенных Смиттом и поддержанных Л.С. Бергом (1948). Анализ пригодности этих критериев для диагностики ряпушек провел Ю.С. Решетников (Сидоров, Решетников, 2014), он же обратил внимание на то, что хорошим видоспецифическим признаком может быть число позвонков, которое у европейской ряпушки в среднем обычно составляет меньше 58 , а у сибирской - больше 60. Именно это обстоятельство и легло в основу нового подхода к диагностике ряпушек. Традиционные пластические признаки, такие как относительная величина антедорсального расстояния (aD) и величина вентроанального расстояния в процентах от $\mathrm{aD}$, стали играть вспомогательную роль.

Ряпушки в водоемах Таймыра встречаются в озерных и в речных системах. В последних (Пясина, Хатанга) они обычно считаются наиболее массовым видом среди сиговых рыб. Их здесь всегда относили к виду
C. sardinella - сибирская ряпушка. Прежде при исследовании меристических признаков у ряпушек из оз. Собачье (Ольшанская, 1967; Максимов и др., 1995) подсчет числа позвонков не проводился (табл. 1).

Наши данные свидетельствуют о том, что собачинская ряпушка по числу позвонков и по ряду пластических признаков может быть диагностирована как европейская (Романов и др., 2016). Следует отметить, что относительно малопозвонковые ряпушки в озерах плато Путорана и бассейна р. Хатанги отмечались нами и ранее (Романов, 2000; Романов, 2004a). Анализ полиморфизма митохондриальной ДНК (мтДНК) ряпушки (Coregonus sp.) оз. Собачье показал значительную близость этой популяции и ряпушек из европейских водоемов - C. albula (Borovikova et al., 2018).

Сиг-валек, валек-Prosopium cylindraceum (Pennant, 1784)

По правобережным притокам Енисея проходит западная граница ареала этого сига. В водоемах Таймырского полуострова и особенно плато Путорана сиг-валек довольно широко распространен, хотя для водоемов Красноярского края он - «краснокнижный вид». Причиной тому является мощный пресс браконьерства в южных притоках Енисея (Туба, Абакан и др.), где он находится на грани исчезновения. В северных притоках Енисея валек встречается в водоемах бассейнов рек Курейки и Хантайки (Романов, 1983; Романов, 2004a; Романов, 2013).

Информация о присутствии в бассейне p. Пясины валька имеется в работе А.Ф. Миддендорфа (Миддендорф, 1869). Эта река еще в 1920-е гг. была почти не изучена. Однако некоторая информация из этого региона в Сибирскую ихтиологическую лабораторию (г. Красноярск) все-таки попадала. В частности, А.И. Березовский (1924), ссылаясь на 
Таблица 1. Некоторые меристические признаки ряпушек из озер Собачье и Лама

Table 1. Some meristic traits of cisco from Lake Sobachye and Lake Lama

\begin{tabular}{|c|c|c|c|c|c|c|c|c|}
\hline \multirow{2}{*}{ Признаки } & \multicolumn{2}{|c|}{$\begin{array}{c}\text { Собачье } \\
\text { (Ольшанская, } \\
1967)\end{array}$} & \multirow{2}{*}{$\begin{array}{c}\begin{array}{c}\text { Собачье } \\
(\text { Максимов и } \\
\text { др., 1995) }(\mathrm{n}=20) \\
\underline{\operatorname{Lim}} \\
\overline{\mathrm{x}} \pm \mathrm{m}\end{array}\end{array}$} & \multicolumn{2}{|c|}{$\begin{array}{c}\text { Собачье } \\
\text { [наши данные] }\end{array}$} & \multirow{2}{*}{ 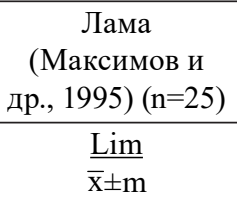 } & \multicolumn{2}{|c|}{$\begin{array}{c}\text { Лама } \\
\text { [наши данные] }\end{array}$} \\
\hline & $\frac{\operatorname{Lim}}{\overline{\mathrm{x}} \pm \mathrm{m}}$ & $\mathrm{n}$ & & $\frac{\operatorname{Lim}}{\overline{\mathrm{x}} \pm \mathrm{m}}$ & $\mathrm{n}$ & & $\frac{\operatorname{Lim}}{\overline{\mathrm{x}} \pm \mathrm{m}}$ & $\mathrm{n}$ \\
\hline$D$ & $\overline{8,58 \pm 0,09}$ & 45 & $\frac{8-10}{8,7}$ & $\frac{7-10}{8,67 \pm 0,07}$ & 60 & $\frac{7-10}{8,6}$ & $\frac{8-10}{8,80 \pm 0,12}$ & 30 \\
\hline$P$ & $\overline{13,27 \pm 0,13}$ & 51 & - & $13 \frac{12-15}{73 \pm 0,09}$ & 60 & - & $\frac{13-15}{13,93 \pm 0,14}$ & 30 \\
\hline$V$ & $\overline{10,32 \pm 0,81}$ & 52 & - & $10, \frac{9-11}{23 \pm 0,06}$ & 60 & - & $\frac{9-11}{10,13 \pm 0,09}$ & 30 \\
\hline$A$ & $\overline{11,77 \pm 0,24}$ & 30 & $\frac{10-12}{11,1}$ & $\frac{10-13}{11,62 \pm 0,11}$ & 60 & $\frac{10-14}{11,6}$ & $\frac{10-14}{11,67 \pm 0,15}$ & 30 \\
\hline Sp.br. & $\overline{48,08 \pm 0,26}$ & 52 & $\frac{39-48}{43,5}$ & $48, \frac{45-54}{83 \pm 0,23}$ & 60 & $\frac{36-47}{42,0}$ & $48 \stackrel{45-57}{37 \pm 0,48}$ & $27 *$ \\
\hline L.l. & $\overline{79,87 \pm 0,68}$ & 52 & $\frac{77-96}{83,1}$ & $\frac{74-87}{79,48 \pm 0,38}$ & 60 & $\frac{73-89}{81,6}$ & $\frac{75-88}{80,72 \pm 0,47}$ & 39 \\
\hline$V t$. & - & - & - & $\frac{55-59}{56,58 \pm 0,12}$ & 73 & - & $\frac{57-63}{58,96 \pm 0,38}$ & 53 \\
\hline
\end{tabular}

Примечание. $D, P, V, A$ - число ветвистых лучей соответственно в спинном, грудном, брюшном и анальном плавниках; $S p . b r$. число жаберных тычинок на первой жаберной дуге; L.l. - число чешуй в боковой линии; Vt. - число позвонков. Над чертой - пределы варьирования; под чертой - средняя \pm ошибка репрезентативности.

* Использованы данные по 15 экз. ряпушки из оз. Лама и 12 экз. из оз. Капчук.

устное сообщение Шмидта, пишет: «...реки Валек, Рыбная и Норильская ... изобилуют вальком». Отсюда были получены два валька, некоторые морфологические признаки которых и были приведены в его публикации. Отдельные данные по морфологии валька представлены в работах Н.А. Остроумова (1937) и М.В. Логашева (1940).

Исследование морфологии вальков некоторых Норило-Пясинских озер, р. Пясины и оз. Аян (Савваитова и др., 1996) дало основание авторам утверждать, что изученные группировки обладают чертами «арктической» и «бореальной» группировок. Ранее такие группировки были выявлены для вальков из водоемов Северо-Востока России (Черешнев, 1991; Черешнев и др., 2002). Арктическая группировка населяет реки арктического побережья, а бореальная - обитает в реках бассейнов западной части Берингова и северной части Охотского морей, т.е. имеется изоляция. Отличия между представителями этих группировок заключались в таких признаках, как число чешуй в боковой линии, число жаберных тычинок, число пилорических придатков и число позвонков. Все признаки имеют значительные зоны трансгрессии, и среди них могут быть приняты для сравнения только число чешуй в боковой линии и число пилорических придатков.

Данные изучения меристических признаков у вальков из бассейна р. Пясины и оз. Аян (басс. р. Хатанги) привели авторов (Савваитова и др., 1996) к заключению о явной неоднородности вальков Таймыра и о возрастании изменчивости морфологических признаков валька на краевых зонах его 
ареала. При этом, согласно данным исследованиям, вальки оз. Аян и р. Пясины оказались обособленными от вальков озер Лама и Собачье. Складывалась весьма любопытная ситуация, когда в одном бассейне р. Пясины обнаружились две фактически симпатричные группировки валька, при этом весьма отличные по некоторым меристическим признакам. Наиболее существенные различия были отмечены в числе чешуй в боковой линии, которых у ламских и собачинских вальков было заметно меньше, чем у пясинских (табл. 2). Хотя у вальков из р. Пясины (25 рыб), по данным этих авторов, число чешуй в боковой линии в среднем составляло 102,0 (lim: 90-120), надо отметить, что объемы выборок были небольшими (от 15 до 25 исследованных рыб). Изучив большую выборку сига-валька, Н.А. Остроумов (1937) приводит данные по среднему числу чешуй в боковой линии - 99,5 (lim: 95-104) и жаберных тычинок - 18,4 (lim: 16-22).
По нашим данным, вальки озер Лама и Собачье в среднем имеют все-таки больше чешуй в боковой линии, чем было определено указанными авторами (табл. 2). Следовательно, все известные группировки валька Таймыра правомочно считать типичными представителями «арктической» группы, и пока нет оснований говорить о большой изменчивости морфологических признаков валька в водоемах Таймыра. Обращает на себя внимание и максимальное число чешуй в боковой линии у вальков в р. Пясине (120). В обзорных работах этот показатель не превышает 109 (Атлас..., 2002; Черешнев, 1991). Наши исследования (исследовано более 300 рыб) меристических признаков у вальков, проведенные в бассейнах рек Хантайки и Пясины, показали, что максимальное число чешуй в боковой линии не превышало 109. Как и в бассейне о3. Хантайского (Романов, 1983), в водоемах Норило-Пясинской системы валек представлен речной и озерно-речной формами.

Таблица 2. Некоторые меристические признаки вальков из озер Собачье и Лама

Table 2. Some meristic traits of round whitefish from Lake Sobachye and Lake Lama

\begin{tabular}{|c|c|c|c|c|c|}
\hline \multirow[t]{2}{*}{ Признаки } & $\begin{array}{c}\text { p. Пясина } \\
\text { (Савваитова и } \\
\text { др., 1996) n=25 }\end{array}$ & $\begin{array}{c}\text { Собачье } \\
\text { (Савваитова и } \\
\text { др., 1996) n=20 }\end{array}$ & $\begin{array}{c}\text { Собачье } \\
\text { [наши данные] } \\
\text { n=33 }\end{array}$ & $\begin{array}{c}\text { Лама } \\
\text { (Савваитова и } \\
\text { др., 1996) n=15 }\end{array}$ & $\begin{array}{c}\text { Лама } \\
\text { [наши данные] } \\
\text { n=40 }\end{array}$ \\
\hline & $\frac{\operatorname{Lim}}{\overline{\mathrm{x}} \pm \mathrm{m}}$ & $\frac{\operatorname{Lim}}{\overline{\mathrm{x}} \pm \mathrm{m}}$ & $\frac{\operatorname{Lim}}{\overline{\mathrm{x}} \pm \mathrm{m}}$ & $\frac{\operatorname{Lim}}{\overline{\mathrm{x}} \pm \mathrm{m}}$ & $\frac{\operatorname{Lim}}{\overline{\mathrm{x}} \pm \mathrm{m}}$ \\
\hline$D$ & $\frac{10-12}{11,64 \pm 0,13}$ & $\frac{10-12}{11,20 \pm 0,14}$ & $\frac{10-13}{11,67 \pm 0,11}$ & $11,00 \pm 0,24$ & $\frac{11-13}{11,98 \pm 0,10}$ \\
\hline$P$ & $\frac{12-14}{13,16 \pm 0,15}$ & $\frac{13-15}{13,95 \pm 0,15}$ & $\frac{13-15}{14,18 \pm 0,09}$ & $13 \frac{11-15}{33 \pm 0,32}$ & $\frac{13-15}{14,43 \pm 0,09}$ \\
\hline V & - & - & $\frac{8-11}{9,76 \pm 0,12}$ & - & $10, \frac{9-11}{13 \pm 0,06}$ \\
\hline$A$ & $\frac{8-11}{9,79 \pm 0,15}$ & $\frac{9-11}{9,65 \pm 0,15}$ & $10, \frac{9-12}{06 \pm 0,13}$ & $\frac{9-13}{10,44 \pm 0,29}$ & $\frac{9-11}{9,80 \pm 0,09}$ \\
\hline Sp.br. & $18 \frac{14-22}{40 \pm 0,40}$ & $\frac{16-20}{18,40 \pm 0,20}$ & $18 \frac{17-21}{70 \pm 0,18}$ & $\frac{18-20}{18,80 \pm 0,20}$ & $\frac{17-22 *}{19,92 \pm 0,14}$ \\
\hline L.l. & $\frac{90-120}{102,0 \pm 1,70}$ & $\frac{80-98}{92,10 \pm 1,00}$ & $\frac{88-103}{95,79 \pm 0,68}$ & $\frac{74-100}{92,70 \pm 1,80}$ & $\frac{93-109 * *}{99,00 \pm 0,51}$ \\
\hline
\end{tabular}

Примечание. Обозначения признаков, как в табл. 1.

$* \mathrm{n}=51 ; * *^{\mathrm{n}}=53$. 
Сибирский хариус - Thymallus arcticus (Pallas, 1776)

Относительно водоемов Таймыра в монографии А.Н. Световидова (1936) предполагалось, что здесь находится западная часть ареала одного из подвидов сибирского хариуса - восточно-сибирского хариуса $T h$. arcticus pallasi Valenciennes 1848. Ареал этого подвида охватывал далее на восток Якутию и Чукотку. Именно восточно-сибирский хариус был определен ранее для водоемов Таймырского полуострова и конкретно для бассейна р. Пясины (Савваитова и др., 1996; Романов, 2004а; Остроумов, 1937; Логашев, 1940; Черешнев, 1991; Ольшанская, 1965; Белых, 1940). В последние годы хариусов Таймыра обычно рассматривают на уровне вида $T h$. arcticus (Pallas) - сибирский хариус (рис. 2). Было показано довольно большое сходство по меристическим признакам и рисунку спинного плавника, обладающего хорошими диагностическим качествами (Макоедов, 1999), между таймырскими хариусами и хариусами из притоков Нижней Оби (Романов, 2007). Ранее были высказаны сомнения в валидности западно-сибирского подвида сибирского хариуса (Романов, 2004б; Романов, 2007). Сибирский хариус из одного из притоков нижней Оби, р. Собь, был описан П.С. Палас- сом, поэтому хариусы бассейна Пясины нами рассматриваются в рамках вида Th. arcticus Pallas.

Несмотря на то, что хариус всегда принадлежал к числу относительно массовых видов рыб, серьезных исследований его в бассейне p. Пясины пока не проводилось. Имеются лишь фрагментарные данные по морфологии этого вида, базирующиеся обычно на небольшом по объему материале и ограниченном числе признаков (Остроумов, 1937; Логашев, 1940; Белых, 1940; Павлов и др., 1999; Романов, 2004а). Всего для анализа морфологических признаков хариуса из оз. Собачье было исследовано 14 самцов и 16 самок (табл. 3, 4). По некоторым меристическим признакам были собраны дополнительные данные.

В расположенном южнее бассейне p. Хантайки ранее была обнаружена симпатрия двух форм (видов) хариусов (Романов, 2004a). Тогда предполагалось, что один из них западно-сибирский, а второй - восточносибирский подвиды сибирского хариуса. Позднее было определено, что тот, который считался западно-сибирским подвидом сибирского хариуса в этом бассейне, генетически аналогичен черному байкальскому хариуcy (Weiss et al., 2007). Сравнение некоторых меристических признаков показало, что отли-

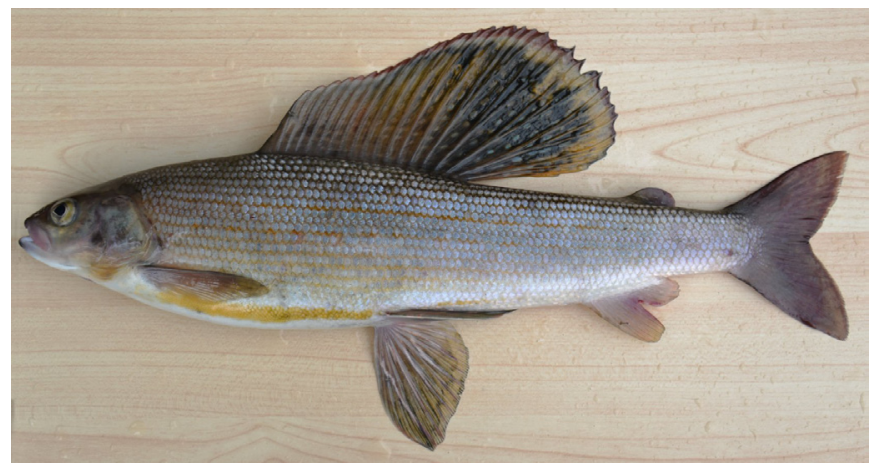

Рис. 2. Сибирский хариус из оз. Собачье (самец, длина по Смитту 384 мм)

Fig. 2. Siberian grayling from Lake Sobachye (male, fork length (FL) is $384 \mathrm{~mm}$ ) 
Таблица 3. Меристические признаки хариуса из оз. Собачье

Table 3. Meristic traits of grayling from Lake Sobachye

\begin{tabular}{|c|c|c|c|c|c|c|}
\hline \multirow{2}{*}{ Признак } & \multicolumn{2}{|c|}{$\mathrm{Lim}$} & \multirow{2}{*}{$\overline{\mathrm{x}}$} & \multirow{2}{*}{$\pm \mathrm{m}$} & \multirow{2}{*}{$\pm \delta$} & \multirow{2}{*}{$\mathrm{n}$} \\
\hline & $\min$ & $\max$ & & & & \\
\hline$D$ & 9 & 12 & 9,91 & 0,10 & 0,73 & 58 \\
\hline D ветв. & 12 & 16 & 13,38 & 0,11 & 0,83 & 58 \\
\hline$D+D$ ветв. & 21 & 25 & 23,29 & 0,13 & 0,96 & 58 \\
\hline$P$ & 14 & 16 & 14,70 & 0,12 & 0,65 & 30 \\
\hline$V$ & 9 & 10 & 9,27 & 0,08 & 0,45 & 30 \\
\hline$A$ & 3 & 4 & 3,70 & 0,09 & 0,47 & 30 \\
\hline А ветв. & 7 & 10 & 8,73 & 0,14 & 0,74 & 30 \\
\hline Sp.br. & 15 & 22 & 18,69 & 0,15 & 1,17 & 58 \\
\hline L.l. $n p$. & 70 & 91 & 81,63 & 0,45 & 3,58 & 63 \\
\hline L.l.np.+ & 73 & 92 & 84,30 & 0,45 & 3,57 & 63 \\
\hline
\end{tabular}

Примечание. $D$ - число неветвистых лучей в спинном плавнике; $D$ ветв. - число ветвистых лучей в спинном плавнике; $D+D$ ветв. - общее число лучей в спинном плавнике; $P$ - число ветвистых лучей в грудном плавнике; $V$ - число ветвистых лучей в брюшном плавнике; $A$ - число неветвистых лучей в анальном плавнике; $A$ ветв. - число ветвистых лучей в анальном плавнике; Sp.br. - число жаберных тычинок; L.l. np. - число прободенных чешуй в боковой линии; L.l. np.+ - общее число чешуй в боковой линии. В последнем признаке учитывались только равные по диаметру чешуи, а мелкие не учитывались.

Таблица 4. Пластические признаки сибирского хариуса из оз. Собачье (30 экз.)

Table 4. Morphometric characteristics of Siberian grayling from Lake Sobachye (30 specimens)

\begin{tabular}{|c|c|c|c|c|c|}
\hline Признаки & $\min$ & $\max$ & $\overline{\mathrm{x}}$ & $\pm \mathrm{m}$ & $\pm \delta$ \\
\hline 1 & 2 & 3 & 4 & 5 & 6 \\
\hline Длина по Смитту, мм & 344,0 & 418,0 & 381,28 & 3,53 & 19,34 \\
\hline \multicolumn{6}{|c|}{ В \% от длины по Смитту } \\
\hline Наибольшая высота тела & 17,3 & 22,7 & 19,72 & 0,22 & 1,23 \\
\hline Наибольшая толщина тела & 10,3 & 12,8 & 11,19 & 0,12 & 0,64 \\
\hline Длина головы & 15,9 & 18,0 & 17,04 & 0,10 & 0,57 \\
\hline Длина хвостового стебля & 12,3 & 15,5 & 14,07 & 0,14 & 0,77 \\
\hline Наименьшая высота тела & 6,7 & 8,1 & 7,38 & 0,06 & 0,35 \\
\hline Антеанальное расстояние & 68,8 & 73,7 & 71,08 & 0,20 & 1,07 \\
\hline Антевентральное расстояние & 44,5 & 47,4 & 45,97 & 0,16 & 0,90 \\
\hline Антедорзальное расстояние & 27,5 & 33,2 & 30,59 & 0,23 & 1,24 \\
\hline Антепектральное расстояние & 15,4 & 18,2 & 16,88 & 0,12 & 0,65 \\
\hline Пектроанальное расстояние & 54,8 & 58,5 & 56,61 & 0,19 & 1,04 \\
\hline Пектровентральное расстояние & 29,6 & 32,2 & 30,90 & 0,16 & 0,86 \\
\hline Вентроанальное расстояние & 24,0 & 29,5 & 26,51 & 0,20 & 1,09 \\
\hline Длина спинного плавника & 22,5 & 27,7 & 25,14 & 0,23 & 1,26 \\
\hline Высота спинного плавника ${ }^{1}$ & 10,3 & 13,4 & 11,63 & 0,16 & 0,87 \\
\hline Высота спинного плавника ${ }^{2}$ & 19,6 & 27,0 & 23,68 & 0,37 & 2,03 \\
\hline Длина анального плавника & 8,1 & 10,3 & 9,13 & 0,11 & 0,63 \\
\hline
\end{tabular}


Продолжение табл. 4

Continued Table. 4

\begin{tabular}{|l|c|c|c|c|c|c|}
\hline \multicolumn{1}{|c|}{1} & 2 & 3 & 4 & 5 & 6 \\
\hline Высота анального плавника & 8,6 & 12,4 & 10,54 & 0,18 & 0,98 \\
Длина грудного плавника & 14,8 & 17,9 & 16,44 & 0,13 & 0,69 \\
Длина брюшного плавника & 16,1 & 19,8 & 17,87 & 0,22 & 1,20 \\
Длина рыла & В \% от длины головы & & \\
Диаметр глаза & 22,6 & 28,4 & 24,90 & 0,25 & 1,36 \\
Заглазничное расстояние & 17,6 & 23,3 & 19,90 & 0,25 & 1,36 \\
Толщина головы & 47,7 & 59,3 & 54,18 & 0,50 & 2,74 \\
Высота головы на уровне глаза & 45,2 & 54,8 & 49,43 & 0,42 & 2,31 \\
Высота головы на уровне затылка & 45,5 & 62,9 & 52,36 & 0,77 & 4,20 \\
Ширина лба & 64,3 & 81,5 & 71,90 & 0,72 & 3,96 \\
\hline
\end{tabular}

Примечание. Высота спинного плавника ${ }^{1}$ - высота последнего неветвистого луча. Высота спинного плавника² - высота наибольшего ветвистого луча.

Таблица 5. Меристические признаки хариусов из водоемов плато Путорана

Table 5. Meristic traits of grayling from water bodies at the Putorana Plateau

\begin{tabular}{|c|c|c|c|c|c|c|}
\hline Вид хариуса & Водоем, авторы & $\begin{array}{c}\text { Неветвистых } \\
\text { лучей в D }\end{array}$ & $\begin{array}{c}\text { Всего лучей } \\
\text { в D }\end{array}$ & $\begin{array}{c}\text { Чешуй в } \\
\text { боковой } \\
\text { линии }\end{array}$ & $\begin{array}{c}\text { Число } \\
\text { жаберных } \\
\text { тычинок }\end{array}$ & Число рыб \\
\hline \multicolumn{7}{|c|}{ Бассейн р. Хантайки } \\
\hline Байкальский & $\begin{array}{l}\text { Оз. Хантайское, } \\
\text { притоки и } \\
\text { р. Хантайка } \\
\text { (Романов, 2004a) }\end{array}$ & $\frac{(5) 6-10}{7,67}$ & $\frac{19-24}{21,29}$ & $\frac{91-123}{101,95}$ & $\frac{15-21}{17,71}$ & 559 \\
\hline Сибирский & $\begin{array}{l}\text { Бассейн } \\
\text { оз. Хантайского } \\
\text { (Романов, 2004a) }\end{array}$ & $\frac{8-12}{9,84}$ & $\frac{21-26}{23,34}$ & $\frac{74-97}{84,82}$ & $\frac{16-23}{19,00}$ & 295 \\
\hline \multicolumn{7}{|c|}{ Бассейн р. Пясины } \\
\hline Сибирский & $\begin{array}{l}\text { Оз. Мелкое } \\
\text { (Логашев, 1940) }\end{array}$ & - & - & $\frac{84-95}{90,1}$ & $\frac{17-21}{19,0}$ & 20 \\
\hline Сибирский & $\begin{array}{l}\text { О3. Собачье } \\
\text { (Павлов и др., 1999) }\end{array}$ & $6-9$ & - & $\frac{77-87}{82,2}$ & $\frac{18-22}{19,86}$ & не указано \\
\hline Сибирский & $\begin{array}{l}\text { О3. Собачье } \\
\text { (наши данные) }\end{array}$ & $\frac{9-12}{9,91}$ & $\frac{21-25}{23,29}$ & $\frac{73-92}{84,30}$ & $\frac{15-22}{20,19}$ & $58-63$ \\
\hline Сибирский & $\begin{array}{l}\text { Оз. Лама } \\
\text { (Павлов и др., 1999) }\end{array}$ & $5-10$ & - & $\frac{78-93}{84,5}$ & $\frac{16-20}{18,0}$ & не указано \\
\hline Сибирский & $\begin{array}{l}\text { Оз. Кета } \\
\text { (наши данные) }\end{array}$ & $\frac{(8) 9-12(13)}{10,24}$ & $\frac{22-26}{23,74}$ & $\frac{81-94}{87,11}$ & $\frac{18-23}{20,19}$ & 89 \\
\hline
\end{tabular}

Примечание. D - число лучей в спинном плавнике; в числителе пределы варьирования признака, в знаменателе его средняя величина. Точное число исследованных рыб из оз. Собачье по меристическим признакам можно найти в табл. 3. 
чия весьма существенны. Для исследования в табл. 5 были использованы только те признаки, по которым отмечены наибольшие различия. Это число неветвистых и общее число лучей в спинном плавнике, число чешуй в боковой линии и числа жаберных тычинок. Несомненно сходство между сибирскими хариусами бассейна оз. Хантайское и оз. Собачье. В материалы по бассейну оз. Хантайское вошли сборы из оз. Кутарамакан, некоторых притоков озера (Гогоченда, Наледная) и Кулюмбинских озер. Река Кулюмбе в настоящее время впадает в Хантайское водохранилище. Близкие характеристики меристических признаков, как и у сибирского хариуса из оз. Собачье, обнаружены у хариуса из оз. Аян (Романов, 2016).

В табл. 5 представлены данные сборов хариусов из оз. Собачье, проведенные ранее (Павлов и др., 1999). К сожалению, объем исследованных рыб в публикации не был представлен. Невысокие показатели числа неветвистых лучей, по сравнению с нашими данными, в спинном плавнике рыб и из оз. Собачье и из оз. Лама, на наш взгляд, связаны с неточностью просчета этого признака.

В дальнейших исследованиях хариусов из водоемов Норило-Пясинских озер необходимо обратить внимание на изучение полового диморфизма этих рыб. По внешней оценке половозрелых хариусов, особенно крупных форм, можно предположить, что диморфизм достаточно выражен.

\section{Эндопаразитофауна рыб}

Паразитофауна рыб оз. Собачье исследована слабо. В 2002-2004 гг. проводилось изучение паразитов промысловых рыб, в результате которого было обнаружено 26 видов паразитов, а озеро было признано природным очагом дифиллоботриоза (Рудковский, Бочарова, 2007).
Всего у исследованных нами рыб оз. Собачье обнаружено 20 видов эндопаразитов, относящихся к пяти систематическим классам (миксоспоридии - 2, цестоды - 6, трематоды - 6, нематоды - 2, скребни - 4) (табл. 6).

Было выявлено наличие возбудителей восьми заболеваний, представляющих угрозу для рыб: язвенной болезни сиговых (H. zschokkei), триенофороза (T. nodulosus), циатоцефалеза (C. truncatus), эуботриоза (E. crassum), диплостомоза (трематоды рода Diplostomum), ихтиокотилуроза (Ichthyocotylurus sp.), метэхиноринхоза лососевых (скребни рода Echinorhynchus) и цистидиколоза лососевых (Cystidicola farionis).

Из обнаруженных видов эндопаразитов для человека представляет опасность цестода D. dendriticum, являющаяся возбудителем дифиллоботриоза. Наиболее подвержена заражению этой цестодой ряпушка, экстенсивность инвазии у которой возросла с $73 \%$ с индексом обилия 4 экз. в 2002-2004 гг. (Рудковский, Бочарова, 2007) до 96 \% при индексе обилия в 8 экз. на хозяина. Кроме того, чаечный лентец, ранее не отмечаемый, появился у сига (ЭИ $=7 \%$; ИО = 0,1 экз.).

Сравнение с предыдущим исследованием паразитофауны рыб оз. Собачье (Рудковский, Бочарова, 2007) демонстрирует увеличение показателей зараженности у ряпушки и сига видами паразитов, передающихся с зоопланктонными организмами (цестоды рода Diphyllobothrium и Proteocephalus). Также увеличились показатели зараженности трематодами рода Crepidostomum хариуса и валька. В паразитофауне ряпушки отсутствует скребень $E$. truttae, отмечаемый ранее; у хариуса, напротив, зарегистрированы два вида скребней (E. cinctulus, E. salmonis), отсутствовавших ранее.

Озеро Собачье является очагом распространения дифиллоботриоза. Наблюдается 
Таблица 6. Состав эндопаразитофауны и показатели зараженности рыб оз. Собачье, 2014 г.

Table 6. Endoparasite fauna and indices of infestation of fishes from Lake Sobachye, 2014

\begin{tabular}{|c|c|c|c|c|}
\hline Вид паразита & Ряпушка & Сиг & Сиг-валек & Хариус \\
\hline Chloromyxum coregoni Bauer, 1948 & $\frac{30,4}{-}$ & - & - & - \\
\hline Henneguya zschokkei (Gurley, 1894) & $\frac{18,2}{0,3}$ & - & - & - \\
\hline Cyathocephalus truncatus (Pallas, 1781) & - & $\frac{33,3}{5,5(1-55)}$ & - & $0, \underline{6,6}$ \\
\hline Diphyllobothrium dendriticum (Nitzsh, 1824) & $\frac{95,6}{7,6(1-67)}$ & $0, \underline{6,6}$ & - & - \\
\hline D. ditremum (Creplin, 1825) & $\frac{95,6}{18,0(3-131)}$ & - & - & - \\
\hline Eubothrium crassum (Bloch, 1779) & - & $\frac{13,3}{0,3(1-3)}$ & - & - \\
\hline Proteocephalus longicollis (Zeder, 1800) & $6 \frac{86,9}{66,4(1-327)}$ & $\frac{46,6}{3,7(1-33)}$ & - & - \\
\hline Triaenophorus nodulosus (Pallas, 1781) & - & - & - & $0, \underline{6,6}$ \\
\hline Diplostomum helveticum (Dubois, 1929) (mc.) & - & $\frac{13,3}{0,1(0-1)}$ & - & - \\
\hline Diplostomum sp.1 (mc.) & - & - & $0,1 \frac{5,5}{(0-1)}$ & - \\
\hline Diplostomum sp.2 (mc.) & - & $0, \underline{6,6}$ & - & - \\
\hline Crepidostomum farionis (Muller, 1780) Luhe, 1909 & - & $2, \frac{46,6}{4(1-17)}$ & $\frac{33,3}{2,9(4-17)}$ & $\frac{93,3}{43,5(2-125)}$ \\
\hline C. metoecus (Braun, 1900) & $\begin{array}{c}4,3 \\
0,1(0-3)\end{array}$ & $\frac{13,3}{0,1(0-1)}$ & $0,1 \stackrel{5,5}{(0-2)}$ & - \\
\hline Ichthyocotylurus sp. & - & $\frac{40,0}{7,6(3-56)}$ & - & - \\
\hline Cystidicola farionis Fischer, 1798 & $\frac{22,7}{3(1-2)}$ & - & $\frac{11,1}{2(1-3)}$ & - \\
\hline Philonema sp. & $\begin{array}{c}\frac{47,8}{47,0(1-} \\
1005)\end{array}$ & - & - & - \\
\hline Echinorhynchus cinctulus (Porta, 1905) & - & $\frac{13,3}{0,1(0-1)}$ & - & $\frac{13,3}{0,4(2-4)}$ \\
\hline E. truttae (Shrank, 1788) & - & $\frac{20,0}{0,2(0-1)}$ & - & - \\
\hline E. salmonis Muller, 1784 & - & $\frac{66,6}{3,4(1-18)}$ & - & $2,6 \frac{13,3}{(11-28)}$ \\
\hline $\begin{array}{l}\text { Neoechinorhynchus (N.) tumidus Van Cleave et } \\
\text { Bangham, } 1949\end{array}$ & - & $\frac{60,0}{2,3(1-12)}$ & - & - \\
\hline
\end{tabular}

Примечание. Над чертой - экстенсивность инвазии (ЭИ), \%; под чертой - индекс обилия (ИО), экз.; в скобках приведены лимиты интенсивности инвазии, экз. Прочерк (-) указывает на невозможность расчета показателя. 
увеличение зараженности ряпушки и сига не только дифиллоботриидами, но и другими видами паразитов, связанных жизненным циклом с зоопланктонными организмами.

\section{Заключение}

Фауна сиговых и хариусовых рыб в о3. Собачье довольно близка к таковой других крупных озер плато Путорана. В то же время отмечено некоторое отличие в составе доминирующих рыб в восточной и западной частях озера. К числу редких представителей восточной части озера относятся сиг-пыжьян, чир, тугун, которые довольно обычны в западной части.

Самым многочисленным видом сиговых в восточной части озера, несомненно, является ряпушка. Исследование ее меристических признаков показало, что относить эту ряпушку к виду C. sardinella - сибирская ряпушка - не вполне оправданно, хотя пока и общепринято. По диагностическим признакам, используемым для сибирской и европейской ряпушек, собачинская ряпушка все-таки ближе к C. albula. Это касается не только числа позвонков, которых у ряпушек из оз. Собачье меньше, и число их довольно близко к европейским популяциям, но и некоторых других признаков (формулы спинного и анального плавников).

По нашим данным, вальки из озер Лама и Собачье практически не отличаются от вальков из других водоемов как плато Пу- торана, так и вообще Таймыра. Особенно это касается числа чешуй в боковой линии, которое используется для дифференциации вальков Субарктики на «арктическую» и «бореальную» группировки. Ранее такое разделение проводилось для вальков из водоемов Северо-Востока России. Следовательно, все известные группировки валька Таймыра правомочно считать типичными представителями «арктической» группы, в то же время нет оснований говорить о большой изменчивости морфологических признаков у сига-валька в водоемах Таймыра.

Как показали наши исследования, хариусовая фауна восточной части оз. Собачье представлена только сибирским хариусом Th. arcticus. Ранее высказывалось предположение (Романов, 2004а) о присутствии в бассейне р. Пясины и другого хариуса, близкого к тому, который в бассейне р. Хантайки считается черным байкальским, - Th. baicalensis Dybowski. Хариус с такими морфологическими признаками был отловлен в р. Талой. Зона его присутствия в бассейне р. Пясины пока не известна, но полученные данные позволяют считать, что в восточной части оз. Собачье его пока нет.

Озеро является природным очагом чаечного дифиллоботриоза. Возбудитель этого заболевания, цестода $D$. dendriticum, встречается у ряпушки и сига. Отмечается увеличение показателей зараженности видами паразитов, связанными жизненным циклом с зоопланктонными организмами.

\section{Благодарность / Acknowledgement}

Авторы выражают благодарность администрации ФГБУ «Заповедники Таймыра» за возможность провести исследования в районе оз. Собачье и помощь со стороны сотрудников заповедника.

The authors are grateful to the joint management of the Taimyr reserves for the opportunity to conduct research at Lake Sobachye and to the staff of the reserve for their assistance. 


\section{Список литературы / References}

Атлас пресноводных рыб России (2002) T. 1. Решетников Ю.С. (ред.) М., Наука, 379 с. [Atlas of freshwater fishes in Russia (2002) Vol. 1. Reshetnikov Yu.S. (ed.) Moscow, Nauka, 379 p. (in Russian)]

Белых Ф.И. (1940) Озеро Лама и его рыбохозяйственное использование. Труды Института полярного земледелия, животноводства и промыслового хозяйства. Серия Промысловое хозяйство, 11: 73-100 [Belykh F.I. (1940) Lake Lama and its fishery use. Transactions of Institute of Polar Agriculture, Breeding and Market Hunting. Series Market Hunting [Trudy Instituta polyarnogo zemledeliya, zhivotnovodstva i promyslovogo hozyaystva. Seriya Promyslovoe hozyaystvo], 11: 73100 (in Russian)]

Берг Л.С. (1948) Рыбы пресных вод СССР и сопредельных стран. Том 1. М.-Л., Изд-во АН CCCP, 466 c. [Berg L.S. (1948) Freshwater fishes of the USSR and adjacent countries. Vol. 1. Moscow, Leningrad, AN SSSR, 466 p. (in Russian)]

Березовский А.И. (1924) О сиговых (Gen. Coregonus) реки Енисея. Труды Сибирской ихтиологической лаборатории, 2(1): 81-97 [Berezovskiy A.I. (1924) Whitefishes from the Yenisei River. Bulletin of Siberian Ichthyological Laboratory [Trudy Sibirskoy ikhtiologicheskoy laboratorii], 2(1): 81-97 (in Russian)]

Быховская-Павловская И.Е. (1985) Паразиты рыб: руководство по изучению. Л., Наука, 121 c. [Bykhovskaya-Pavlovskaya I.E.(1985) Fish parasites: study guide. Leningrad, Nauka, 121 p. (in Russian)]

Дрягин П.А., Пирожников П.Л., Покровский В.В. (1969) Полиморфизм сиговых рыб (Coregonidae) и его биологическое и рыбохозяйственное значение. Bопросы ихтиологии, 9(1): 14-25 [Dryagin P.A., Pirozhnikov P.L., Pokrovskiy V.V. (1969) Polymorphism of whitefishes (Coregonidae) and its biological and fishery value. Journal of Ichthyology [Voprosy ikhtiologii], 9(1): 14-25 (in Russian)]

Заделенов В.А., Глущенко Л.А., Матасов В.В., Шадрин Е.Н. (2015) Ихтиофауна больших норильских озер (Кутарамакан, Лама, Собачье). Научные труды ФГБУ «Объединенная дирекиия заповедников Таймыра». Выпуск 1. Норильск, АПЕКС, с. 116-130 [Zadelyonov V.A., Glushchenko L.A., Matasov V.V., Shadrin E.N. (2015) Ichthyofauna of large Norilsk lakes (Kutaramakan, Lama, Sobachye). Transactions of FGBU «Incorporated Directorate of Taimyr reserves». Issue 1. Norilsk, APEKS, p. 116-130 (in Russian)]

Заделенов В.А., Шадрин Е.Н., Матасов В.В., Романов В.И. (2014) К биоразнообразию гольцов больших Норильских озер: голец-пучеглазка оз. Собачьего. Современное состояние водных биоресурсов: мат-лы 3-й междунар. конф. Новосибирск, с. 46-50 [Zadelyonov V.A., Shadrin E.N., Matasov V.V., Romanov V.I. (2014) Biodiversity of char from large Norilsk lakes: char-pucheglazka from Lake Sobachye. Current state of aquatic bioresourses. Proceedings of the $3^{\text {rd }}$ International Conference. Novosibirsk, p. 46-50 (in Russian)]

Лакин Г.Ф. (1980) Биометрия. М., Высшая школа, 293 с. [Lakin G.F. (1980) Biometrics. Moscow, Vysshaya shkola, 293 p. (in Russian)]

Ледяев О.М., Романов В.И. (1991) Пути рационального рыбохозяйственного использования разнотипных озер юга Таймырского полуострова. Рыбопродуктивность озер Западной Сибиpu. Новосибирск, Наука, с. 80-82 [Ledyaev O.M., Romanov V.I. (1991) Ways in rational fisheries 
using different types of south lakes on the Taimyr Peninsula. Fish capacity of West Siberian lakes. Novosibirsk, Nauka, p. 80-82 (in Russian)]

Логашев М.В. (1940) Озеро Мелкое и его рыбохозяйственное использование. Труды Института полярного земледелия, животноводства и промыслового хозяйства. Серия Промысловое хозяйство, 11: 7-72 [Logashev M.V. (1940) Lake Melkoe and its fishery use. Transactions of Institute of Polar Agriculture, Breeding and Market Hunting. Series Market Hunting [Trudy Instituta polyarnogo zemledeliya, zhivotnovodstva i promyslovogo hozyaystva. Seriya Promyslovoe hozyaystvo], 11: 7-72 (in Russian)]

Макоедов А.Н. (1999) Родственные отношения хариусов Сибири и Дальнего Востока. М., 108 c. [Makoedov A.N. (1999) Taxonomy of grayling in Siberia and the Far East. Moscow, 108 p. (in Russian)]

Максимов С.В., Савваитова К.А., Пичугин М.Ю. (1995) Сибирская ряпушка Coregonus sardinella из водоемов Норило-Пясинской водной системы. Вопросы ихтиологии, 35(4): 445454 [Maksimov S.V., Savvaitova K.A., Pichugin M.Yu. (1995) Least cisco Coregonus sardinella from Norilsk-Pyasina water system. Journal of Ichthyology [Voprosy ikhtiologii], 35(4): 445-454 (in Russian)]

Миддендорф А.Ф. (1869) Путешествие на Север и Восток Сибири: Север и Восток Сибири в естественно-историческом отношении. Ч. 2, отд. 5. Сибирская фауна. СПб., Типография Императорской Академии наук, 310 с. [Middendorf A.F. (1869) Journey to the North and East of Siberia: North and East of Siberia in the natural-historical aspect. Part 2, Section 5. Siberian fauna. Saint Petersburg, Typography of the Imperial Academy of Sciences, 310 p. (in Russian)]

Михайлова Е.И. (2010) О значении признака, предложенного В.Я. Трофименко для разграничения видов Neoechinorhynchus crassus Van Cleave, 1919 и N. tumidus Van Cleave et Bangham, 1949 (Acanthocephales: Neoechinorhynchidae). Труды Центра паразитологии ИПЭЭРАН. Т. 46. М., Наука, с. 148-155 [Mihaylova E.I. (2010) The significance of the trait proposed by V.Ya. Trofimenko to distinguish between the Neoechinorhynchus crassus Van Cleave, 1919 and N. tumidus Van Cleave et Bangham, 1949 (Acanthocephales: Neoechinorhynchidae) species. Transactions of IEE RAS Parasitology Centre. Vol. 46. Moscow, Nauka, p. 148-155 (in Russian)]

Ольшанская О.Л. (1964) Ряпушка бассейна реки Пясины. Труды Сибирского отделения ГосНИОРХ. Т. 8. Красноярск, с. 157-159 [Olshanskaya O.L. (1964) Cisco from the Pyasina River basin. Proceedings of Siberian Branch of the State Research Institute of Lake and River Fisheries. Vol. 8. Krasnoyarsk, p. 157-159 (in Russian)]

Ольшанская О.Л. (1965) Обзор ихтиофауны р. Пясины. Вопросы ихтиологии, 5(2): 262278 [Olshanskaya O.L. (1965) Overview of Pyasina ichthyofauna. Journal of Ichthyology [Voprosy ikhtiologii], 5(2): 262-278 (in Russian)]

Ольшанская О.Л. (1967) Ряпушка системы реки Пясины. Труды Красноярского отделения СибНИИРХ, 9: 94-213 [Olshanskaya O.L. (1967) Cisco of the Pyasina River water system. Proceedings of Krasnoyarsk Branch of the Siberian Research Institute of Fish Industry [Trudy Krasnoyarskogo otdeleniya SibNIIRH], 9: 94-213 (in Russian)]

Определитель паразитов пресноводных рыб фауны СССР (1984) T. 1. Паразитические простейшие. Бауер О.Н. (ред.) Л., Наука, 431 с. [Identification guide to fish parasites of 
the USSR fauna (1984) Vol. 1. Parasitic protozoa. Bauer O.N. (ed.) Leningrad, Nauka, 431 p. (in Russian)]

Определитель паразитов пресноводных рыб фауны СССР (1985) Т. 2. Паразитические многоклеточные (1-я часть). Бауер О.Н. (ред.) Л., Наука, 425 с. [Identification guide to fish parasites of the USSR fauna (1985) Vol. 2. Parasitic metazoa (Part 1). Bauer O.N. (ed.) Leningrad, Nauka, 425 p. (in Russian)]

Определитель паразитов пресноводных рыб фауны СССР (1987) Т. 3. Паразитические многоклеточные (2-я часть). Бауер О.Н. (ред.) Л., Наука, 583 с. [Identification guide to fish parasites of the USSR fauna (1987) Vol. 3. Parasitic metazoa (Part 2). Bauer O.N. (ed.) Leningrad, Nauka, 583p. (in Russian)]

Остроумов Н.А. (1937) Рыбы и рыбный промысел р. Пясины. Труды полярной комиссии, 30: 3-115 [Ostroumov N.A. (1937) Fish and fishery of the Pyasina River. Proceedings of the Arctic Committee, 30: 3-115 (in Russian)]

Павлов Д.С., Савваитова К.А., Груздева М.А., Максимов С.В., Медников Б.М., Пичугин М.Ю., Савоскул С.П., Чеботарева Ю.В., Павлов С.Д. (1999) Разнообразие рыб Таймыра: Систематика, экология, структура видов как основа биоразнообразия в высоких широтах, современное состояние в условиях антропогенного воздействия. М., Наука, 207 с. [Pavlov D.S., Savvaitova K.A., Gruzdeva M.A., Maksimov S.V., Mednikov B.M., Pichugin M.Yu., Savoskul S.P., Chebotareva Yu.V., Pavlov S.D (1999) Fish diversity of the Taimyr: Systematics, ecology, species structure as the basis of the biodiversity in high latitudes, current state under human impact. Moscow, Nauka, 207 p. (in Russian)]

Павлов С.Д., Савваитова К.А., Максимов В.А. (1994) О взаимоотношениях симпатрических группировок арктических гольцов в озере Собачье (Норило-Пясинская водная система). Систематика, биология и биотехника разведения лососевых рыб. Матер. пятого Всерос. совеш. СПб, Изд-во ГосНИОРХ, с. 148-151 [Pavlov S.D., Savvaitova K.A., Maksimov V.A. (1994) Relationships between sympatric groups of Arctic char in Lake Sobachye (Norilo-Pyasinskaya water system). Systematics, biology and methods of breeding of salmonid fishes. Proceedings of $5^{\text {th }}$ AllRussian Meeting. St. Petersburg, GosNIORH, p. 148-151 (in Russian)]

Пармузин Ю.П. (1981) Морфологические черты озер. Озера северо-запада Сибирской платформы. Новосибирск, Наука, с. 15-21 [Parmuzin Yu.P. (1981) Morphological features of lakes. Lakes on the northwest of Siberian Platform. Novosibirsk, Nauka, p. 15 - 21 (in Russian)]

Пирожников П.Л., Дрягин П.А., Покровский В.В. (1975) О таксономическом ранге и филогении сиговых (Coregonidae, Pisces). Известия ГосНИОРХ, 104: 5-17 [Pirozhnikov P.L., Dryagin P.A., Pokrovskiy V.V. (1975) Taxonomic rank and phylogeny of whitefishes (Coregonidae, Pisces). Bulletin of GosNIORH [Izvestiya GosNIORH], 104: 5-17 (in Russian)]

Правдин И.Ф. (1966) Руководство по изучению рыб. М., Пищепромиздат, 376 с. [Pravdin I.F. (1966) Fish study guide. Moscow, Pishchepromizdat, 376 p. (in Russian)]

Решетников Ю.С. (1980) Экология и систематика сиговых рыб. М., Наука, 301 с. [Reshetnikov Yu.S. (1980) Ecology and systematics of whitefishes. Moscow, Nauka, 301 p. (in Russian)]

Романов В.И. (1983) К вопросу об экологической структуре валька Prosopium cylindraceum (Pallas et Pennant) в пределах азиатской части ареала. Биологические проблемы Севера. Тези- 
сы Х Всесоюзного симпозиума. Часть 2. Животный мир. Магадан, с. 205-206 [Romanov V.I. (1983) Ecological structure of round whitefish Prosopium cylindraceum (Pallas et Pennant) within the Asian part of its range. Biological problems of the North. Book of abstracts of $10^{\text {th }}$ All-Soviet Union symposium. Part 2. Wild animals. Magadan, p. 205-206 (in Russian)]

Романов В.И. (2000) Морфо-экологическая характеристика ряпушки из озера Томмот (бассейн р. Хатанги) и некоторые дискуссионные вопросы систематики евразийских ряпушек. Сибирский экологический журнал, 7(3): 293-304 [Romanov V.I. (2000) Morphoecological characteristics of Coregonus from the Lake Tommot (River Khatanga Basin) and some disputable questions of European Coregonus systematics. Contemporary Problems of Ecology [Sibirskij ekologicheskij zhurnal], 7(3): 293-304 (in Russian)]

Романов В.И. (2004а) Ихтиофауна плато Путорана. Фауна позвоночных животных плато Путорана. М., с. 29-89 [Romanov V.I. (2004a) Ichthyofauna of the Putorana Plateau. Vertebrate fauna of the Putorana Plateau. Moscow, p. 29-89 (in Russian)]

Романов В.И. (2004б) Некоторые особенности изменчивости морфологических признаков у западносибирского хариуса Thymallus arcticus arcticus (Pallas). Вестник ТГУ. Приложение. Материаль III Междун. конф. «Проблема вида и видообразование», № 10. c. 107-111 [Romanov V.I. (2004b) Specific variability of morphological traits in West Siberian grayling Thymallus arcticus arcticus (Pallas). Tomsk State University Journal. Supplement. Proceedings of the $3^{\text {rd }}$ Internat. Conf. "Problems of species and speciation", No. 10. p. 107-111 (in Russian)]

Романов В.И. (2007) О статусе западносибирского подвида сибирского хариуса (Thymallus arcticus arcticus): анализ некоторых меристических признаков. Исследования по ихтиологии и смежным дисииплинам на внутренних водоемах в начале XXI века (к 80-летию профессора Л.А. Кудерского). СПб., Издание ФГНУ «ГосНИОРХ» и «Товарищество научных изданий КМК», c. 436-452 [Romanov V.I. (2007) The status of West Siberian subspecies of Arctic grayling (Thymallus arcticus arcticus): analysis of some meristic traits. Studies in ichthyology and related sciences for inland waters. St. Petersburg, FGNU “GosNIORH”, KMK, p. 436-452 (in Russian)]

Романов В.И. (2013) Валек Prosopium cylindraceum (Pennant, 1784) в водоемах западной границы своего ареала. Биология, биотехника разведения и состояние запасов сиговых рыб. Тюмень, ФГУП «ГОСРЫБЦЕНТР», с. 188-194 [Romanov V.I. (2013) Round whitefish Prosopium cylindraceum (Pennant, 1784) in the waters at the western border of its range. Biology, breeding methods and state of whitefish stocks. Tyumen, FGUP «GOSRYBCENTR», p. 188-194 (in Russian)]

Романов В.И. (2016) Морфологическая изменчивость сибирского хариуса (Thymallus arcticus (Pallas, 1776)) из разнотипных озер бассейна реки Хатанги (полуостров Таймыр) в связи с адаптациями к горным и равнинным условиям. Известия Иркутского университета. Серия «Биология. Экология», 18: 45-57 [Romanov V.I. (2016) Morphological differences of Arctic grayling Thymallus arcticus (Pallas, 1776) from lakes in Khatanga's river basin (Taimyr Peninsula) associated with the adaptations to the mountain and plain habitats. The Bulletin of Irkutsk University. Series "Biology. Ecology", 18: 45-57 (in Russian)]

Романов В.И., Петлина А.П., Бабкина И.Б. (2012) Методы исследования пресноводных рыб Сибири. Томск, Изд-во Томск. ун-та, 256 с. [Romanov V.I., Petlina A.P., Babkina I.B. (2012) Methods of investigating fresh-water fish in Siberia. Tomsk, TSU, 256 p. (in Russian)]

$$
-427 \text { - }
$$


Романов В.И., Заделенов В.А., Никулина Ю.С., Поляева К.В. (2016) Морфология и паразитология ряпушки озера Собачьего (плато Путорана). Вестник НГАУ, 38 (1): $69-77$ [Romanov V.I., Zadelenov V.A., Nikulina Yu.S., Polyaeva K.V. (2016) Morphology and parasitology of the Sobachye Lake Coregonus albula L. (Plateau Putorana). Bulletin of the Novosibirsk State Agrarian University [Vestnik NSAU], 38(1): 69-77 (in Russian)]

Рудковский А.И., Бочарова Т.А. (2007) Инвазии промысловых рыб озера Собачье на юге Таймыра. Ихтиологические исследования на внутренних водоемах. Саранск, с. 131-133 [Rudkovskiy A.I., Bocharova T.A. (2007) Infestations of commercial fishery species from Lake Sobachye in the south of Taimyr. Ichthyological research in inland water bodies. Saransk, p. 131-133 (in Russian)]

Савваитова К.А., Груздева М.А., Максимов С.В. (1996) К вопросу о популяционной структуре валька Prosopium cylindraceum в водоемах Таймыра. Вопросы ихтиологии, 36(2): 195-205 [Savvaitova K.A., Gruzdeva M.A., Maksimov S.V. (1996) Round whitefish (Prosopium cylindraceum) population structure in Taymyr water bodies. Journal of Ichthyology [Voprosy ikhtiologii], 36(2): 195205 (in Russian)]

Световидов А.Н. (1936) Европейско-азиатские хариусы (Genus Thymallus Cuvier). Tpyды Зоологического института АН СССР, 3: 183-301 [Svetovidov A.N. (1936) Euro-Asian grayling (Genus Thymallus Cuvier). Transactions of Zoological Institute AN USSR [Trudy Zoologicheskogo Instituta AN SSSR], 3: 183-301 (in Russian)]

Сидоров Г.П., Решетников Ю.С. (2014) Лососеобразные рыбы водоемов европейского Северо-Востока. М., Тов-во науч. Изданий КМК, 346 с. [Sidorov G.P., Reshetnikov Yu.S. (2014) Salmoniformes in European Northeast water bodies. Moscow, KMK, 346 p. (in Russian)]

Соловкина Л.Н. (1974) Ряпушка Coregonus albula sardinella (Val.) бассейна Печоры. Bonpoсы ихтиологии, 14(5): 769-781 [Solovkina L.N. (1974) Vendace Coregonus albula sardinella (Val.) of the Pechora basin. Journal of Ichthyology [Voprosy ikhtiologii], 14(5): 769-781 (in Russian)]

Черешнев И.А. (1991) Популяционная структура чира и обыкновенного валька СевероВостока Азии. Современные проблемы сиговых рыб. Ч. 1. Владивосток, ДВО АН СССР, с. 38-49 [Chereshnev I.A. (1991) Population structure of round-nosed whitefish and round whitefish in Northeast Asia. Modern problems of whitefishes. Part 1. Vladivostok, FEB AS USSR, p. 38-49 (in Russian)]

Черешнев И.А., Волобуев В.В., Шестаков А.В., Фролов С.В. (2002) Лососевидные рыбы Северо-Востока России. Владивосток, Дальнаука, 496 с. [Chereshnev I.A., Volobuev V.V., Shestakov A.V., Frolov S.V. (2002) Salmonid fishes of Russia's North-East. Vladivostok, Dalnauka, 496 p. (in Russian)]

Amin O.M. (2002) Revision of Neoechinorhynchus Stiles \& Hassal, 1905 (Acanthocephala: Neoechinorhynchidae) with keys to 88 species in two subgenera. Systematic Parasitology, 53(1): 1-18

Amin O.M. (2013) Classification of acanthocephala. Folia Parasitologica, 60(4): 273-305

Borovikova E.A., Romanov V.I., Nikulina J.S. (2018) Morphological and genetic features of cisco (Coregonidae: Coregonus sp.) from lake Sobachye (Putorana plateau). Russian Journal of Genetics: Applied Research, 8(1): 37-43

Rozsa L., Reiczigel J., Majoros G. (2000) Quantifying parasites in samples of hosts. Journal of Parasitology, 86(2): 228-232 
Weiss S., Knizhin I., Romanov V., Kopun T. (2007) Secondary contact between two divergent lineages of grayling Thymallus in the lower Enisey basin and its taxonomic implications. Journal of Fish Biology, 71: 371-386 